\title{
O Espírito Santo na vida de Jesus Por uma Cristologia Pneumática
}

\author{
Luiz Fernando Ribeiro Santana
}

\section{Introdução}

No Antigo Testamento fala-se do Espírito Santo como aquele sopro de Deus (ruah) que cria, dá a vida e repousa sobre certos eleitos, investindo-os de poderes extraordinários com a finalidade de combater, governar, executar diversos trabalhos e profetizar. Sobretudo é em expoentes como Jeremias, Ezequiel e Joel que, de forma mais expressiva, pode-se constatar a marcante transição da atuação externa e pública da ruah de Iahweh para uma perspectiva mais interior e profundamente pessoal, onde o Espírito do Senhor é visto como aquele que age no coração de cada fiel, capacitando todo o povo de Deus à experiência de uma renovação interior e à novidade do coração em vista da aliança que o Senhor projetava contrair com os seus (cf. Jr 31,31-34; Ez 36,24-28; J1 3,1-5).

Inaugurando a Nova Aliança, é em seu Filho amado que o Pai pode, enfim, levar a termo o seu desígnio de salvar e renovar todos os homens. Jesus abre a toda a história o caminho para a releitura das promessas messiânicas. É sob essa luz e seguindo a esteira messiânica que os apóstolos interpretaram os textos messiâncos que falavam da ruah e viram em Jesus o descendente de Davi dotado da plenitude do Espírito do Senhor. Assim, a efusão penumática, objeto da promessa, é agora destinada a todos os povos, e "aquele que crer" pode colher os ricos e abundantes dons do Espírito Santo, frutos da fecunda árvore plantada no solo do Mistério Pascal de Jesus (vidapaixão-morte-ressusrreição-efusão do Espírito Santo-nascimento da Igreja). 


\section{O Espírito Santo nas Origens de Jesus}

O Kerygma primitivo, que nos chega através dos Atos dos Apóstolos, transmite-nos em forma de testemunho que, com o Messias Jesus, é chegada a época da efusão do Espírito do Senhor, predita tantas vezes pelos profetas. Esta efusão, considerada a partir do enfoque veterotestamentário, caracteriza claramente a chegada dos "últimos tempos", isto é, o tempo da plena realização das promessas de Deus ao seu povo.

O Antigo Testamento havia intuído que o Messias seria revestido do Espírito de Iahweh e que este mesmo Espírito repousaria definitivamente sobre o "rebento do tronco de Jessé" (cf. Is 11,1ss) ${ }^{1}$. Aquele Espírito que revestia os carismáticos do Antigo Testamento e os capacitava para missões precisas, deveria, nos "ultimos tempos", ser infundido plenamente no Filho de Deus, o Messias, o descendente de Davi, plenitude e centro de toda a revelação bíblica.

Com o Evento "Cristo", temos a estrada aberta para uma leitura dos textos messiânicos do Antigo Testamento. O próprio Jesus, na Sinagoga de Nazaré (cf. Lc 4,16ss), aplica a si o trecho profético do Trito-Isaías acerca da unção do Espírito do Senhor (cf. Is 61,1ss). O Messias deveria ser o rei ideal graças ao Espírito de Iahweh, e ainda, segundo a corrente messiânica tão presente nos Atos dos Apóstolos, o Servo de Iahweh, também receberia a consagração do Espírito, a fim de que pudesse levar a Torah às nações ${ }^{2}$.

Todo o ser e o operar de Jesus, à luz daquilo que narram os Atos dos Apóstolos e os Evangelhos Sinóticos, estão sob o sinal de um Kerygma, que se torna real e comunicável graças à potência dinâmica do Espírito. Considerada em sua globalidade, a vida de Jesus é interpretada como fenômeno messiânico todo envolvido num mistério pneumático. Por ora interessa-nos considerar o mistério da encarnação sob seu perfil pneumático ${ }^{3}$.

${ }^{1}$ Cf.F.LAMBIASI, Lo Spirito Santo: Mistero e Presenza..., p. 38: "Ha ragione Giovanni Paolo II nell'enciclica sullo Spirito Santo nel ritenere questo passo come di grande importanza per tutta la pneumatologia dell'AT; si tratta di un vero e proprio "ponte" tra la nozione antica di "spirito" inteso soprattutto come "soffio carismatico" e la rivelazione neotestamentaria dello Spirito come persona e come dono (DeV 15)".

${ }^{2}$ Cf. A.JANKOWSKY, Gesù e Spirito, in AA.VV., Atti del Congresso Teologico Internazionale di Pneumatologia, Vol. I, Vaticano, Libreria Editrice Vaticana, 1983, p. 742; cf. ainda: R.KOCH, Le Christ et l'Esprit du Seigneur selon Luc 4,18-19, in Nouvelle Revue Théologique 115 (1993), pp. 877-885.

${ }^{3}$ Cf. AA.VV., Comissão Teológico-Histórica do Grande Jubileu do Ano 2000, Jesus Cristo: Ontem, Hoje e Sempre, São Paulo, Paulinas, 1996, p. 171: “O Mistério da Encarnação do Filho de Deus está inteiramente subordinado à Virtus Pneumática do Espírito Santo. Da Encarnação ao Pentecostes, o acontecimento "Cristo" encontra no Espírito Santo o seu dinamismo fundamental". 
Segundo antiga compreensão bíblica, Deus se mostra como Aquele que, por excelência, gera, dá a vida ${ }^{4}$. Em S1 2,7 temos a seguinte declaração posta nos "lábios" de Deus: "Tu és o meu filho, eu hoje te gerei". Paulo, em sua pregação querigmática aos judeus, mostra que o "hoje" do cumprimento pleno dessa passagem é a ressurreição de Jesus, razão pela qual se utiliza do trecho do salmo na construção de seu discurso (cf. At 13,33). Deus, dessa forma, se nos apresenta como Aquele que revela a sua paternidade ao gerar seu Unigênito e, através d'Ele, tudo o que foi chamado à existência (cf. $\mathrm{Cl}$ 1,15-16; Ef 1,3-4). É ele o "primogênito de Deus" e o primeiro a receber a unção do Espírito, já ao ser gerado antes do tempo, o que nos é bem ilustrado por Cirilo de Alexandria no seu comentário ao evangelho de Lucas ${ }^{5}$. A obra de gerar ou engendrar eternamente o Seu unigênito é uma missão realizada com uma grande alegria e um supremo prazer por parte do Pai; pode-se dizer que é esta a obra que mais compraz e deleita o Eterno Criador ${ }^{6}$.

Acompanhando as diversas etapas da história da salvação, deparamonos com aquela que Paulo chama de pléroma, na qual, no tempo previamente determinado, o Filho de Deus "nasce de uma mulher" (cf. Gl 4,4). Ele

${ }^{4}$ Cf. G.VON RAD, Teologia del Antiguo Testamento, Salamanca, Sigueme, 1975, pp. 286, 292, 354, 391 e 505.

${ }^{5}$ Cf. PG 72, 525 C: “Aquele que é o primogênito entre nós recebe por primeiro o Espírito, ainda que ele mesmo seja o doador do próprio Espírito, para que, dele, nos seja doado o Consolador, nos seja comunicada a graça do próprio Paráclito de santidade."; cf. ainda: G.MARTELET, L'Esprit Saint et la Genération du Christ, in Lumen Vitae 27 (1972), pp. 596597: "Mais en créant cet univers comme le corps cosmique de l'humanité à venir, Dieu crée non moins et plus encore le corps cosmique de Celui qui deviendra, par le chemin de l'homme, le Seigneur de l'homme et de son monde. C'est donc des le debut, que Celui sera révélé comme "le Premier né de toute créature $(\mathrm{Cl} 1,15)$ est déjà impliqué dans la genèse initiale du monde"; J.PABLO MARTIN, El Espiritu Santo en los Origines del Cristianismo, Zürich, Pas-Verlag, 1971, p. 231: "Para Justino, "Cristo" no es solamente una denominación extrínseca de esta persona, sino un nome que descubre un significado: el Ungido... Cristo goza no solamente de una generación pré-cósmica e transcendente, sino también de una Unción pre-cósmica. Cristo es adorable por ser Dios y Ungido". Note-se ainda que "segundo alguns Padres, houve ainda antes a unção que o Verbo tinha recebido do Pai em vista da criação do mundo para que, por sua vez, "ungisse e ornasse todas as coisas" (desta "unção cósmica" falam Justino e Irineu)." (Cf. R.CANTALAMESSA, O Espírito Santo na Vida de Jesus, São Paulo, Loyola, 1987, p. 8).

${ }^{6}$ Cf. E.M.HEUFELDER, El Espiritu ora en Nosotros, Salamanca, Secretariado Trinitario, 1983, p. 37: “Angel Silesio dice esto mismo: "El nacimento espiritual que tiene lugar en mí es uno con aquel por el que el Padre engendra al Hijo. La alegria y el placer supremo que Dios me puede conceder es que quiere engendrarme eternamente como hijo suyo. La obra que más complace a Dios es engendrar su Hijo en ti”. Diga-se ainda que, sendo fonte da eterna Alegria, Iahweh tudo cria e opera no deleite de Sua Alegria. A Alegria, nesse sentido, é uma outra forma de falar do Espírito do Senhor; "Alegria" e "Espírito", segundo a teologia vétero e neotestamentária são conceitos afins que expressam a mesma realidade. 
nasce como um homem que foi concebido na carne pela virtude do Espírito Santo ou na sua "sombra" e seu "poder" (cf. Mt 1,20; Lc 1,35). O mistério dessa concepção virginal pode ser visto como uma nova e radical criação, cujo protagonista é o mesmo Espírito que outrora fecundou e tornou possível a primeira criação ${ }^{7}$."Maria diz "sim" e o Espírito se manifesta, Espírito que une o Verbo ao sim, a energia divina e a energia humana, o dom e o acolhimento. Dessa aliança, finalmente consumada, entre o Verbo e a carne, o Espírito do Pai é o artífice... Aquele que vai nascer da Filha de Sião não é concebido por um querer humano nem por um determinismo de causas, mas pelo poder do Espírito Santo" $"$.

É de nosso interesse ressaltar aqui o perfil pneumatológico do mistério da encarnação e da união hipostática. $\mathrm{O}$ agente operante desse mistério é o Espírito que, como Pessoa-Amor e Dom incriado, consubstancial ao Pai e ao Filho, é, ao mesmo tempo, o sujeito da autocomunicação de Deus, fonte primeira de todos os dons e do próprio Dom incriado ${ }^{9}$. Na encarnação do Filho, o Espírito se encontra hipostaticamente unido a Ele, como o é desde toda a eternidade; sobre Ele permanece e repousa, n'Ele realizando o desígnio de Deus ${ }^{10}$.

No seio da Trindade, o Espírito Santo é o vínculo de amor eterno entre o Pai e o Filho; na encarnação torna-se vínculo de união entre o Verbo e a humanidade (cf. Jo 1,14). A partir do testemunho dos evangelhos sinóticos, em particular de Lucas, verificamos que as pessoas e as circunstâncias que

${ }^{7}$ Cf. M.DUPUY, L’Esprit, Souffle du Seigneur, Paris, Desclée, 1988, p. 44: "La première mention de l'Esprit dans l'Evangile de Mathieu est d'une nouveauté radicale. Nulle part dans l'Ancien Testament il n'était question d'un tel rôle pour l'Esprit et les épitres n'en parlent pas davantage: La conception virginal de Jésus n'est pas œuvre d'un homme, mais est due à l'Esprit Saint. La génération de Jésus se trouve ainsi comparée à rien de moins qu'à la création: de même que l'Esprit (Gn 1,2) a présidé à l'origine (genesis) du ciel et de la terre (Gn 2,4 ), il est à l'origine (genèse - Mt 1,18) de Jésus". O tema da fecundidade virginal aparece, no Novo Testamento, via de regra, associado ao Espírito Santo".

${ }^{8}$ J.CORBON, Liturgia de Fonte, São Paulo, Paulinas, 1981, p. 26; cf. Catecismo da Igreja Católica (Doravante citado como CIC), n. 702: "Desde o começo até à plenitude do tempo (G1 4,4), a missão conjunta do Verbo e do Espírito do Pai permanece escondida, mas está em ação. O Espírito de Deus prepara aí o tempo do Messias, e os dois, sem serem ainda plenamente revelados, já são prometidos a fim de serem esperados e acolhidos quando se manifestarem. É por isso que a Igreja, quando lê o Antigo Testamento, procura nele o que o Espírito, que falou pelos profetas, quer falar-nos a respeito de Cristo".

9 JOÃO PAULO II, Carta Encíclica Dominum et Vivificantem - "O Espírito Santo na Vida do Mundo", São Paulo, Paulinas, 1987(Citado como DeV ), n. 50.

10 Cf. D.STANILOAE, La Preghiera di Gesú e lo Spirito Santo, Roma, Città Nuova, 1990, pp.78-79: "Lo Spirito, come ipostasi, riposa in permanenza sul Figlio anche durante la sua incarnazione. E colui che si rivela nel battesimo, quando lo Spirito appare tra il Padre e il Figlio incarnato, unendoli in qualche modo e muovendosi dall'uno all'altro". 
envolvem a encarnação e o nascimento de Jesus gravitam em torno da ação do Espírito: O precursor será "repleto do Espírito desde o seio de sua mãe" (Lc 1,15); Zacarias, "repleto do Espírito Santo", profetiza que aquela criança será chamada profeta do Altíssimo (Lc 1,67); José é informado de que "o que nela se gerou é obra do Espírito Santo" (Mt 1,20); Isabel, ao saudar Maria e o que nela havia sido concebido, "ficou cheia do Espírito Santo" (Lc $1,42)$; a Simeão é revelado pelo Espírito Santo que não veria a morte antes de ter visto o Cristo Senhor (Lc 2,26).

O Espírito Santo é prometido a Maria como a "força do Altíssimo" que a cobre com "sua sombra" $(\mathrm{Lc} 1,35)$ e nela realiza o desígnio amoroso do Pai. Segundo a expressão de E.Cavalcanti, a potência criadora do Altíssimo "fabricou o Corpo de Cristo" no seio da Virgem Maria; seguindo a autora, essa cristologia penumática encontra-se respaldada na tradição dos Padres da Igreja ${ }^{11}$. Concebendo por obra do Espírito Santo, Maria apresentase como a nova arca da Aliança inaugurada na plenitude dos tempos, sobre a qual está a glória de Deus na sua potência fecundante; de fato essa glória nos lembra a nuvem luminosa que, no Antigo Testamento, era o sinal da presença de Deus em meio ao seu povo (cf. Ex 13,22; 19,16). Em todo o seu ser, é ela a pneumatófora (portadora do Espírito) por excelência no plano das criaturas e instrumento dócil à intervenção santificadora do Espírito no plano da Salvação ${ }^{12}$.

${ }^{11}$ E.CAVALCANTI, Interpretazioni di Luca 1,35, nel Dibattito sullo Spirito Santo prima del Concilio, in Credo in Spiritum Sanctum, AA.VV., Atti del Congresso Teologico Internazionale di Pneumatologia in occasione del I Concilio di Costantinopoli e del $1550^{\circ}$ Anniversario del Concilio di Efeso, Roma, 22-26 marzo 1982, Vol. I, Libreria Editrice Vaticana, 1983, pp. 95-96: "Nel De Spiritu Sanctu di Didimo abbiamo un ampio testo compreendenti i paragrafi 31 e 32 (PG 39,1062 A-C), in cui molto marcatamente Lc 1,35 è utilizzato per dimostrare la natura divina dello Spirito in base al suo potere creatore che operò nell'incarnazione: “...A Maria l'angelo disse: "Lo Spirito Santo scenderà su di te e la potenza dell'Altissimo ti coprirà" (Lc 1,35). Quindi la potenza creatrice dell'Altissimo, con la discesa dello Spirito Santo nella Vergine Maria, fabbricò il corpo de Cristo, che Egli, nato senza seme di uomo, usò come tempio. Da tutto ciò si dimostra che lo Spirito Santo è creatore... E nel salmo, al Signore si dice: 'Togli loro il tuo Spirito e muoiono, e ritornano nella loro polvere. Mandi il tuo Spirito e sono creati, e rinnovi la faccia della terra' (Ps 103,29-30). Né è da stupirsi che lo Spirito Santo sia creatore del corpo del Signore, così come, insieme con il Padre e il Figlio, con lo stesso potere, ha creato tutte le cose che il Padre creò e il Figlio creò... La radice di questa teologia è chiaramente atanasiana ed ha alle spalle la tradizione della cristologia pneumatica".

${ }^{12}$ Cf. PAULO VI, O Culto da Virgem Maria, São Paulo, Loyola, 1974, n. 26: "A reflexão teológica e a Liturgia têm vindo a salientar, de fato, que a intervenção santificadora do Espírito no caso da Virgem de Nazaré foi um momento culminante da sua ação na História de Salvação. Assim, por exemplo, alguns Santos Padres e escritores eclesiásticos atribuíram à obra do Espírito a santidade original de Maria, por ele "como que plasmada e tornada uma nova criatura"; cf. ainda: A.M.TRIACCA, "Ex Spiritu Sancto regeneratus" - La presenza e l'azione 
De modo bem característico, Lucas apresenta o Espírito como o grande protagonista do evento da encarnação do Verbo, a tal ponto de podermos falar em uma unção fundamental e constitutiva da pessoa de Cristo. Como protagonista da encarnação, não se pode deixar de sublinhar a ligação ôntica do feminino com o Espírito Santo no mistério da encarnação. Tal como no relato de Gn 1,2, o Espírito, como poder fecundante, desce sobre Maria e, com sua ação materna e epiclética, nela gera o Cristo. Conforme mencionado anteriormente, torna-se importante em nossos dias redescobrir a vertente maternal do Espírito Santo, tão negligenciada, sobretudo pela teologia ocidental. Sabemos que já no Antigo Testamento Iahweh se mostra como um Pai que possui entranhas maternas (cf. Os 11,8; Jr 4,19; 31,9b.15-20; Is $66,13.15$ ).

Considerando o agir trinitário-econômico de Deus ao longo da revelação bíblica, não podemos negligenciar a pessoa do Espírito como "amor materno incriado", que procede do Pai pelo Filho. Sua atuação, em geral, estará relacionada aos elementos indicadores da maternidade: gerar, fecundar, renovar, confortar, consolar.
"Alguns Padres da Igreja chamaram o Espírito Santo de mãe divina de Jesus homem, porque a concepção no seio da Virgem Maria acontece por obra e graça do Es- pírito Santo (Mt 1,18). Macario, grande teólogo cristão da Síria (334), nos deixou este belo texto: $O$ Espírito é a nossa mãe porque o Paráclito, o consolador, está pron- to a consolar-nos como uma mãe consola seu filho e porque os fiéis são renascidos d'Ele, sendo, assim, fi- lhos desta Mãe misteriosa, que é o Espirito Santo"13.

\footnotetext{
dello Spirito Santo testemoniate nel "Missale Gothicum" (Da un sustrato patristico a una viva preghiera), in S.FELICI, (Org.), Convegno di Studio e Aggiornamento dalla Facoltà di Lettere Cristiane e Classiche (Pontificium Institutum Altirioris Latinitatis), Roma 6-7 marzo 1982, Roma, Libreria Ateneo Salesiano, 1983, p. 263: "La "Ecclesía", costituita nello Spirito, è iniziata con una sua azione, come il Verbo entra nella storia per mezzo della "regeneratio ex Spiritu Sancto". Da quel momento, "ex Maria et ex Spiritu Sancto", incomincia il tempo di Cristo che è pure il tempo dello Spirito. E se con Cristo iniziano gli ultimi tempi, è proprio perché l'Unto di Dio, per mezzo dello Spirito, guida i figli adottivi del Padre teleologicamente alla vita eterna".

${ }^{13}$ L.BOFF, La Trinità: La Migliore Comunità, Assisi, Cittadella Editrice, 1990, p. 143; cf. ainda: M.C.L.BINGEMER: Donna: Temporalità ed Eternità - La Donna Eterna e il Volto Femminile di Dio, in Concilium 6 (1991), pp. 113-124 e O Segredo Feminino do Mistério, Petrópolis, Vozes, 1991, pp. 129-134. Quanto à questão da "Mística do Feminino" e da relação "Feminino-Espírito" na história da salvação, consultar o interessante estudo de C.MiLitello, Ruah - Lo Spirito Santo: Un Punto de Vista Femminile, in Manderò il mio Spirito su tutti - L'Ecumenismo nella Forza dello Spirito, Dehoniane, Roma, 1994, pp. 431-
} 
Nascido por obra do Espírito Santo, Jesus é, desde o princípio, um "tabernáculo" do Espírito, um pneumático no sentido pleno do que esse termo pode significar. Segundo a teologia lucana é exatamente este traço fundamental do ser de Jesus que caracterizará a sua futura atividade messiânica. Dessa maneira, podemos constatar que, no evento da encarnação, o papel do Espírito aparece como decisivo. Se, por um lado, o aspecto cristológico é fortemente marcante nos relatos bíblicos sobre a encarnação, por outro lado, não se pode ignorar ou minorar o seu teor pneumatológico. Somente a partir dessas duas vertentes se chega à plenitude da revelação inaugurada com a encarnação do Verbo eterno, onde, finalmente, as promessas antigas são cumpridas e algo radicalmente novo é instaurado na história dos homens com o advento do Salvador.

A Igreja recolheu esse dado revelado da dimensão pneumática da encarnação e, desde cedo, o introduziu no seu Símbolo da Fé. Desde o fím do segundo século, temos no "Símbolo Apostólico" a menção segundo a qual Jesus "nasceu do Espírito Santo e da Virgem Maria”. O Concílio Ecumênico de Constantinopla (ano de 381), que definiu a divindade do Espírito Santo, colocou este artigo também no Símbolo Niceno-Constantinopolitano, onde vemos que Cristo "encarnou-se do Espírito Santo e da Virgem Maria".

\section{O Espírito Santo no Batismo de Jesus}

Concluída a tratativa da ação do Espírito no mistério da encarnação, urge que passemos a considerar a importância de primeira grandeza que o evento histórico-teológico do batismo exerceu na vida de Jesus ${ }^{14}$.

434. A.Orbe no terceiro capítulo de sua obra La Teología del Espíritu Santo, intitulado "O Espírito e a Maternidade Divina”, mostra-nos como a tradição cristã, desde os primórdios, percebeu com clareza a índole feminina e virginal do Espírito Santo, a ponto de qualificar o Espírito como "Mãe do Verbo" (ainda que este título dado ao Espírito esteja também presente em alguns sistemas heterodoxos, como é o caso das Acta Thomae e do "Evangelho dos Hebreus") - cf. A.ORBE,La Teología del Espíritu Santo, Roma, Editrice Pontificia Università Gregoriana, 1966, pp. 105-116.

14 Cf. A.LÓPEZ TRUJILlO, La Renovación del Espíritu, in Consejo Episcopal LatinoAmericano-CELAM, Renovación en el Espíritu. Movimientos Carismaticos en America Latina, Bogotá, Celam, 1975, p. XII: "El relato del bautismo hecho como una teofanía, está seguramente influído por la misma liturgia del bautismo cristiano y es en cierto modo como un preludio de Pentecostés. Talvez está en la intención de los Sinópticos al indicar el símbolo de la paloma que se trate de una nueva creación. Jesús, concebido virginalmente por la fuerza creadora del Espíritu de Dios. "El Espíritu Santo descenderá sobre ti y la virtud del Altísimo te cubrirá con su sombra" (Lc 1,35), el Bautista ve bajar del cielo al Espíritu como una paloma a la manera como el "Espíritu de Dios aleteaba sobre la superfície de las aguas" (Gn 1,2) la mañana de la primera creación. Comenta R. Koch que el Espíritu de Dios (Ruah), como viento, aura suave se cernía sobre las aguas primeras como fuerza fecundante, volando como un pájaro de aqui para allá 
Segundo o pensamento cristão da primeira hora e a catequese da Igreja primitiva, o batismo de Jesus no Jordão, o mistério da sua unção, constitui o primeiríssimo princípio da Igreja ${ }^{15}$. O acontecimento do batismo de Jesus é de tal forma decisivo para a vida de Cristo e dos cristãos que as investigações exegéticas mais recentes têm demonstrado que existe uma íntima relação entre os relatos sobre o batismo de Jesus e a catequese batismal da Igreja primitiva; isso equivale a dizer que, em virtude da experiência póspentecostal do Espírito, as narrações acerca do batismo de Jesus de Nazaré se constituíram em "princípio hermenêutico" para a auto-compreensão da fé cristã $^{16}$.

O testemunho mais importante sobre a concepção da Igreja primitiva acerca do batismo de Jesus como o mistério da sua unção, nós o encontramos no seguinte trecho da pregação de Pedro na casa de Cornélio: "Sabeis o que aconteceu por toda a Judéia: Jesus de Nazaré, começando pela Galiléia, depois do batismo proclamado por João, como Deus o ungiu com o Espírito Santo e com poder, ele que passou fazendo o bem e curando a todos os que estavam dominados pelo diabo, porque Deus estava com ele" (At 10,37-38).

Esta declaração é uma expressão clara de um tema fundamental do anúncio apostólico: no batismo de Jesus se via o início da sua obra pública, que seria culminada na sua morte e ressurreição ${ }^{17}$. A mencionada perícope é a única passagem dos Atos dos Apóstolos, praticamente, em que se fala expressamente da unção de Jesus com o Espírito Santo; em passagens como At 2,36;5,42, encontramos a menção de Jesus que foi constituído Senhor e Cristo por Deus, o que equivale dizer o seguinte: o que em At 10,37-38 está ex-

(Gn 1,2), o como después del diluvio, trajo la paloma en su pico un ramo de olivo, signo de la paz para la humanidad nueva encarnada en el Mesías (Gn 8,11)".

${ }^{15}$ Cf. H.MÜHLEN, Fé Cristã Renovada, São Paulo, Loyola, 1980, p. 147: “Aquele que há de batizar com o Espírito Santo (Mc 1,8 e paral., cf. At 1,8), foi ele mesmo, no princípio da sua atividade pública, batizado com o Espírito Santo"; cf. D.VIGNE, Le Baptême du Christ, Onction Paradisiaque, in Nouvelle Revue Théologique 112 (1990), pp. 801-820.

${ }^{16}$ Cf. L.F.LADARIA, La Cristología de Hilario de Poitiers, Roma, Editrice Pontitificia Università Gregoriana, 1989, p. 105: "El Bautismo del Señor es un acontecimiento de capital importancia según el Nuevo Testamento y la Tradición de la Iglesia.”; cf. ainda: Id. Ibid., El Bautismo y la Unción de Jesús en Hilario de Poitiers, in Gregorianum 70 (1989), pp. 277-290.

${ }^{17}$ Cf. A.HAMMAN, El Espíritu Santo en la vida de la Iglesia durante los Tres Primeros Siglos, in AA. VV., El Espíritu Santo Ayher y Hoy, Salamanca, Secretariado Trinitario, 1975, p. 148: "Existe una maravillosa continuidad desde el nacimiento de Jesús, "la primera unción de la humanidad por la divinidad", hasta la solemne proclamación en el Jordán, epifanía de la economia divina, que culmina con la comunidad que el Espíritu reúne en torno al Resucitado y con el nacimiento de nuevos bautizados. Agregados al cuerpo de Cristo por el bautismo, que restituye la justicia a toda la estirpe adámica, los cristianos reciben a su vez, como Jesús, la unción del Espíritu y, de ahí, su nombre de cristianos que significa ungidos; están "marcados en el corazón con el sello del Espíritu, que se nos ha dado como arras". 
plícito, nas passagens anteriormente citadas fica subentendido. No relato em questão fica esclarecido que foi exatamente com o batismo e a unção de Jesus que teve início tudo aquilo que se tornou o conteúdo nuclear da pregação dos apóstolos. A unção de Jesus no Jordão marca o começo da obra pública do redentor, por isso esse acontecimento, vivamente presente na mente dos primeiros cristãos, tem um lugar primordial na história da salvação ${ }^{18}$.

É de particular interesse para nós a expressão: "Deus ungiu com o Espírito Santo e com poder a Jesus de Nazaré". É uma clara referência a Is 61,1, onde se fala da unção profética (Pneûma Kyríou ep'emè, hoû heíneken échrisé me...). Lembremo-nos de que, ao iniciar seu ministério público na Galiléia, Jesus, tomando o profeta Isaías, aplica a si e ao seu ministério a passagem de Is 61,1-2, nela reconhecendo a síntese de sua missão messiânica (cf. Lc 4,18-19) ${ }^{19}$.

A unção pneumática do Jordão impulsiona Jesus a anunciar a boa notícia aos pobres. A descida do Espírito Santo sobre Ele é uma unção profética que, enquanto lhe confere o crédito junto aos homens, confirma o seu mandato divino, corrobora sua investidura messiânica e instaura sua obra de servo sofredor. Por causa da unção recebida no batismo e renovada em todo o seu ministério público, Jesus plenifica os tempos messiânicos, onde as promessas que anunciavam a libertação cedem lugar ao "já" do cumprimento. Como outrora o profeta era um sinal de Iahweh e agia sob a ação da potência da sua Ruah, ao longo de seu ministério público Jesus é a presença do kairós divino; na qualidade de "ungido pelo Espírito", Ele é, no grau mais alto, o "sacramento" da presença de Deus em meio ao seu povo.

A pregação apostólica das origens era formalmente delimitada pela noção do testemunho, da realidade "vista" e "ouvida" do "batismo de Jesus até a sua ressurreição e ascensão" (cf. At 1,21.22; 10,37-41). Nesse sentido, o batismo de Jesus se apresenta como um dos eventos mais atestados na

\footnotetext{
${ }^{18}$ Cf. H.MÜHLEN, Una Mystica Persona, Roma, Città Nuova, 1968, p. 272: "ll battesimo e l'unzione sono l'inizio (arché) dell'opera pubblica del Redentore; perciò questo fatto, presente in modo particolare alla mente dei primi fedeli, ha um posto di primo piano nella storia della salvezza". De forma diferente do que, em geral, acontecia com aqueles que eram ungidos no Antigo Testamento, Jesus não foi ungido com um ungüento material (cf. 1Rs 19,16; 1Sm 9,26), mas com o Espírito Santo, o que pode ser constatado com o dativo instrumental usado no versículo em At 10,38. O "Pneûma" é, então, o próprio ungüento com o qual Jesus é ungido. Isso fica mais explícito, se confrontarmos At 10,38 com 1Jo 2,20.27, em que se fala que nós "temos recebido a unção do Santo. "Para a compreensão da Igreja, é agora importante constatarmos que no batismo de Jesus no Espírito, aconteceu também algo com o próprio Espírito Santo: tornou-se algo que Ele anteriormente não era: 'chrîsma' = 'óleo, como disse uma vez Basílio Magno” (H.MÜHLEN, Fé Cristã Renovada..., p. 151).

${ }^{19}$ Cf. R.KOCH, Le Christ et l'Esprit du Seigneur selon Luc 4,18-19, in Nouvelle Revue Théologique 115 (1993), pp. 877-885.
} 
tradição dos apóstolos. Nos relatos fornecidos pelos sinóticos (Mt 3,13-17; Mc 1,9-11; Lc 3,21-22), a descida do Espírito Santo sobre Jesus é o elemento central de todo o acontecimento, e mesmo o que lhe confere seu significado próprio.

F.Lambiasi mostra que é através do batismo que Jesus "nasce" como "Cristo", isto é, consagrado. Esclarece que esse "nascimento messiânico" não pode ser tomado no sentido adocionista, como pretendiam os gnósticos, os quais sustentavam que, no momento do batismo, o salvador celeste havia descido sobre Jesus.

\begin{abstract}
"De fato, sob o perfil ontológico, Jesus é o Filho de Deus pela união hipostática desde sua concepção. O Espírito, assim, está presente em Jesus antes do batismo, mas sob o perfil da "economia", isto é, do desenvolvimento ordenado e progressivo da história da salvação, é no batismo que Jesus, de modo novo, é "constituído" não só declarado - Filho de Deus para nós. Após ter descido sobre Maria, o Espírito desce novamente no Jordão para inaugurar a atividade do Messias, que culminará na ressurreição quando Jesus será "constituído Filho de Deus com poder segundo o Espírito de santificação" $(\mathrm{Rm} 1,4)$ ". ${ }^{20}$
\end{abstract}

Y.Congar, em concordância com o que foi anteriormente exposto, diz que, embora Jesus fosse o Filho de Deus e estivesse habitado pelo Espírito desde o seio materno, o batismo "inaugura um novo capítulo" em sua vida e em seu ministério. Isso porque, através deste evento, inicia-se uma "nova missão ou comunicação" no ser e no ministério messiânico do Verbo encarnado. Neste acontecimento Jesus é constituído e declarado "Messias"; é testificado como aquele sobre quem repousa o Espírito e como aquele que operará em virtude da potência do Espírito ${ }^{21}$.

Antes de considerarmos o papel do Espírito no ministério messiânico de Jesus, é oportuno acenarmos que todo o mistério de sua pessoa está sob a influência e orientação do mesmo Espírito. R.Cantalamessa, em seu estudo sobre o batismo e a unção de Jesus, mostra como, desde a aurora da Igreja, houve uma tendência de a cristologia se transferir, aos poucos, dos eventos ou dos mistérios concretos da vida de Cristo para a encarnação, onde o problema do fundamento da salvação (como é feito o Salvador) toma a dianteira sobre o problema do desenvolvimento real da salvação (o que o Salvador

\footnotetext{
${ }^{20}$ F.LAMBIASI, Lo Spirito Santo: Mistero e Presenza..., p. 54.

${ }^{21}$ Y.M.J.CONGAR, Revelação e experiência do Espírito, São Paulo, Paulinas, 2005, pp. 32-33.
} 
faz). Isso, em grande parte, foi gerado pelas tendências gnósticas e suas seqüelas no arianismo e gnosticismo; acrescido a isso, temos ainda o forte pendor da ontologização da cultura grega (à qual pertencia a maioria dos Padres), onde o que conta, acima de tudo, é a arché das coisas, a sua constituição metafísica e não o seu devir na história. Nesse sentido, o batismo de Jesus tende mais a ser um mistério cristológico só em sentido ativo (o que opera o Cristo), e não também em sentido passivo (o que em Cristo é operado). De fato, a idéia da unção de Jesus pela ação do Espírito Santo não chega a desaparecer da teologia, mas a carga de transferência pesa, sobretudo, para o momento da encarnação, até ser identificada com a própria encarnação ${ }^{22}$.

\begin{abstract}
"A conseqüência mais notável disso é o enfraquecimento da dimensão pneumática da cristologia, isto é, a diminuição da atenção que deveria ser dada à ação do Espírito Santo na vida de Jesus... Entre os latinos, com o advento da Escolástica, o mistério e a própria idéia da unção de Cristo por obra do Espírito santo no dia do seu batismo desaparecem por completo da teologia, já que nunca foram tratados como questão em nenhuma das Summas, a partir de Santo Tomás. Com o Concílio Vaticano II, esse mistério reaparece na consciência da Igreja., ${ }^{23}$
\end{abstract}

Em Rm 1,4, por exemplo, é dito que Jesus foi "estabelecido Filho de Deus com poder por sua ressurreição dos mortos, segundo o Espírito de santidade". Certamente aqui se pensa na santidade pneumática de Jesus manifestada com a sua ressurreição e não em algum ofício messiânico que lhe conferisse a condição de Filho de Deus. Embora o trecho não fale explicitamente de unção, ela fica subentendida quando se acena ao "Espírito de santidade". Assim, segundo a mentalidade dos primeiros cristãos, a unção experimentada por Jesus no batismo não está apenas em função de sua missão messiânica, mas também se torna causa de sua própria santidade e fonte da nossa graça santificante ${ }^{24}$.

\footnotetext{
${ }^{22}$ Cf. R.CANTALAMESSA, O Espírito Santo na Vida de Jesus..., pp. 8-11.

${ }^{23}$ Id. Ibid., Ungidos pelo Espírito, São Paulo, Loyola, 1996, p. 17.

${ }^{24}$ Cf. H.MÜHLEN, Una Mystica Persona..., p. 275; Cf. C.DUQUOC, Sainteté de Jésus et Sainteté de l'Esprit, in Concilium 149 (1979), p. 92: "Jésus est Saint parce qu'il laisse opérer en lui l'Esprit créateur, séparant des normes imposées par le passé: il entre hardiment dans une création nouvelle dont la forme est insoupçonnable et dont le chemin est mortel". Ainda verificar: F.C.REHBEIN, A Experiência do Espírito, Experiência de Doação e Compromisso, Dissertação de Mestrado, Mimeo., PUC-RJ, 1978, p. 11: "Jesus é o Ungido porque o Espírito de Deus está sobre ele (Lc 4,18ss), porque o Pai o ungiu com o seu Espírito (At 4, 27;10,38), isto é, o Pai lhe comunicou a plenitude de seu Espírito".
} 
Nas passagens mencionadas acerca do batismo de Jesus não se fala de "ungir"; diz-se apenas que o Pneûma "desceu" sobre ele (cf. Mc 1,10 e paralelos). Vimos que somente em At 10,38 é que, expressamente, fala-se de "unção". Entretanto não só os citados trechos não se contradizem como se complementam, uma vez que a teologia da "unção" tem uma base muito ampla. É a partir dela que os primeiros cristãos entenderam que o Espírito Santo, manifestado no batismo, dava um significado a toda a obra salvífica de Jesus. Ele é o "Cristo", o "Messias", justamente porque foi ungido pelo Espírito Santo.

Sem dúvida alguma, o acontecimento do batismo e a experiência que Jesus fez do Espírito no Jordão é algo radicalmente marcante e pessoal, antes de tudo. Lucas diz que no momento do batismo Jesus estava em oração; deixando-se orientar pela voz do céu que ali ecoava, Jesus é declarado o "Filho predileto" do Pai (cf. Lc 4,21-22). Pela imagem da pomba que desce, também usada pelos Sinóticos, os evangelhos querem nos mostrar a comunicação inaudita que ali está-se dando, onde o Espírito de Deus, sob o véu da imagem, está pairando, concebendo e inaugurando algo novo na pessoa de Jesus. "Jesus foi de tal modo mergulhado, quer dizer, 'batizado', no Espírito Santo que foi por Ele tocado e penetrado até na sua corporeidade, o que pôde ser visto e ouvido também pelos presentes. Jesus é aquele que há de batizar no Espírito Santo, e o Espírito que desce sobre Ele indica-O como o "Batista Espiritual", anunciado e prometido"25.

Prosseguindo um pouco mais em seu comentário, H.Mühlen afirma que o acontecimento do batismo para Jesus era, ao mesmo tempo, uma "irrupção carismática". Ali Ele se encontra "mergulhado, em intensidade inimaginável, no mar da auto-entrega divina, surgindo novamente dele como a testemunha corporal dessa auto-entrega divina" ${ }^{26}$. Os exegetas redescobrem, sempre mais, a importante significação existencial que a experiência pneumática do Jordão teve na vida de Jesus. Tal importância não se refere apenas àquilo que Jesus operou naquela ocasião (a santificação das águas), mas ainda e, sobretudo, àquilo que n'Ele ocorreu de inédito: "Sentimo-nos autorizados a supor que precisamente naquele momento Jesus aceitou a sua vocação"27. Não no sentido de que antes não a tivesse aceito, mas "porque uni-

\footnotetext{
${ }^{25}$ H.MÜHLEN, Fé Cristã Renovada..., p. 149; cf. ainda M.J.GUILLOU, Le Developpement de la Doctrine sur l'Esprit Saint dans les Ecrits du Nouveau Testament, in Credo in Spiritum Sanctum, Atti del Congresso Teologico Internazionale di Pneumatologia, Vol. I, Vaticano, Libreria Editrice Vaticana, 1983, p. 732: "La colombe qui vient se poser sur Jésus, au Baptême, semble bien un rappel significatif de l'Esprit planant sur le chaos lors de la création: C'est une nouvelle création que s'inaugure".

${ }^{26}$ Cf. H.MÜHLEN, op. cit., p. 151.

${ }^{27}$ C.H.DODD, citado por R.CANTALAMESSA, O Espírito Santo na Vida de Jesus..., p. 12.
} 
camente nesse ponto de seu crescimento em sabedoria e graça, como todo homem, esta se manifestou a Ele de modo claro e concreto"28.

A unção batismal de Jesus inaugura uma nova etapa em sua vida, cria uma novidade no seu itinerário espiritual e na sua missão messiânica ${ }^{29}$. Esse fato será de capital importância também para a vida da Igreja no que concerne à sua espiritualidade e à sua vocação fundamental, que é, precisamente, a de tomar parte na unção de Cristo e, assim, participar do dom da salvação; naturalmente, a mesma realidade é, com toda a propriedade, aplicada a cada cristão. Com efeito, S.Irineu assim nos diz: "O Espírito de Deus desceu sobre Jesus e o ungiu, como prometera nos profetas, para que pudéssemos participar da plenitude de sua unção e, assim, ser salvos" (Adversus Haeresis III,9,3) ${ }^{30}$. É

${ }^{28}$ Id.Ibid.: " 'Foi no momento do batismo que Jesus adquiriu a certeza de que devia assumir o papel do servo de Javé' (O.Cullmann). Com efeito, a voz celeste (cf. Mc 1,11) proclama as palavras que, em Isaías 42,1, são dirigidas ao servo de Iahweh sobre o qual se diz que Ele "pôs o seu Espírito". É nesse momento, pois, que se verifica a fusão na consciência de Jesus (enquanto consciência também humana) das duas figuras ideais do Messias e do servo de Iahweh, fusão que determinará, doravante, a identidade e a novidade messiânica de Jesus e dará um cunho inconfundível a toda sua palavra e ação". Conferir: A.S.PANOMOLLE, $A s-$ colta la Parola - Anno Liturgico C/1, M.Masini (Org.), Padova, Edizioni Messaggero Padova, 1988, pp. 151-152: "Per il terzo evangelista, Gesù é ripieno di Spirito Santo. La scena del battesimo al Giordano descrive la venuta di questa persona divina, sotto forma corporea di colomba Gesù (Lc 3,22). Da questo momento Cristo é posseduto, guidato e animato dallo Spirito Santo: egli, pieno di Spirito Santo... Per Luca, infatti, il Cristo é davvero l'uomo dello Spirito, perché è animato e guidato solo e sempre da questa persona divina. In tal modo Gesù è presentato come il perfetto "spirituale", come il modello di docilità allo Spirito".

${ }^{29}$ Cf. A.M.TRIACCA, «Ex Spiritu Sancto regeneratus» - La presenza e l'azione dello Spirito Santo testemoniate nel «Missale Gothicum» (Da un Sustrato Oatristico a una Viva Preghiera), in FELICI, S. (Org.), Spirito Santo e Catechesi Patristica, Roma, Libreria Ateneo Salesiano, 1983, p. 247: "Dio unse di Spirito Santo e di potenza Gesù di Nazareth" (Atti 10,38), questo è un apoftegma del kerygma iniziale nella predicazione degli Apostoli. All'unzione di Gesù al Giordano è legato il mandato dell'ufficio messianico"; e ainda: A.G.RUBIO, O Encontro com Jesus Cristo Vivo, São Paulo, Paulinas, 1994, p. 28: "O batismo constitui um momento forte na explicitação da consciência messiânica de Jesus. É também um sinal de sua vida de servidor que acabará por conduzi-lo à morte (cf. Lc 12,50). Como servidor, aliás, Jesus carrega os pecados do povo (cf. Is 53,lss). Agora podemos compreender porque Jesus é batizado junto com o povo: como Servo de Iahweh, Ele é solidário com seus irmãos, com o povo pecador".

${ }^{30}$ Cf. G.BENTIVEGNA, Il Battesimo dello Spirito - Testemonianze dalla Chiesa dei Padri, Roma, Soc. Coop. Rinnovamento nello Spirito p. 43: "Nel nome di Cristo è sottinteso sia colui che ha operato l'unzione sia colui che è unto sia l'unzione stessa della quale è stato unto... sia il Padre che opera l'unzione, sia il Figlio che riceve questa unzione, sia l'unzione stessa che è lo Spirito. Quel Gesù, su cui senza misura si è "precipitata" l'unzione dello Spirito, dopo avere ricevuta quest'unzione dal Padre, la estende generosamente a tutto il genere umano (cfr. Lc 4,18); cf. A.ORBE, El Espíritu en el Bautismo de Jesús, in Gregorianum 76 (1995), pp. 671-672: Jesus foi ungido para que participássemos da sua unção e fôssemos salvos. 
graças a essa participação na unção de Cristo é que a Igreja pode ser definida, conforme no-lo atesta o Concílio Vaticano II, verdadeira e propriamente como "Povo de Deus", isto é, povo de consagrados ao Senhor (cf. LG 9).

Convém ressaltar que a unção recebida por Jesus no Jordão teve um cunho eminentemente trinitário, no sentido de que as três Pessoas divinas tomaram parte naquele evento. Segundo São Basílio, “dizer Cristo é confessar toda a Trindade: significa de fato mostrar o Deus que ungiu, o Filho que foi ungido e a unção que é o Espírito Santo. Testemunha-o Pedro nos Atos, dizendo que "Deus ungiu de Espírito Santo Jesus de Nazaré" (At 10,38); de igual maneira o afirma Isaías quando diz: "O Espírito do Senhor está sobre mim, porque me ungiu" (Is 61,1). Por sua vez, o salmista proclama: "Deus, teu Deus, te ungiu com o óleo da alegria" (S1 44,8)". (De Spiritu Sancto XII; PG 32,116s). Conforme anteriormente assinalado, o ungido do Senhor haveria de inaugurar "a era do Espírito e da alegria"31, dons afins a serem largamente derramados nos tempos messiânicos. Assim, batizado no Jordão, Jesus se revela a toda a humanidade como Aquele que, por excelência, foi "ungido com o óleo da alegria anunciado pelo profeta Davi"32. A teofania do Jordão (cf. Mt 3,13-17; Mc 1,9-11; Lc 3,21-22) vem nos mostrar que o Amor do Pai, versado sobre seu Filho em forma de "unção da alegria", no batismo, é personificado no Espírito Santo, sendo também este Amor o nexus amoris entre Um e Outro. Procedendo do Pai (o que unge), o Espírito Santo (o un-

\footnotetext{
31 A.MARTINELLI, Lo Spirito di Dio e la Gioia nell'Antico Testamento, Bologna, Edizioni Francescane Bologna, 1976, p. 15. A este respeito conferir: Catequeses de Jerusalém - Cat. Mystagogica 21, 3,1-3; PG 33,1087-1091, em Oficio das Leituras, Ave-Maria, Paulinas, Paulus, Vozes, 1995, pp. 547: "Cristo jamais foi ungido por homem, seja com óleo ou com outro ungüento material. Mas o Pai, ao predestiná-lo como Salvador do mundo inteiro, ungiuo com o Espírito Santo. É o que nos diz Pedro: "Jesus de Nazaré foi ungido por Deus com o Espírito Santo" (At 10,38). E o profeta Davi cantava: Vosso trono, ó Deus, é eterno, sem fim; vosso cetro real é sinal de justiça: vós amais a justiça e odiais a maldade. É por isso que Deus vos ungiu com seu óleo, deu-vos mais alegria que aos vossos amigos (S1 44,7-8). Cristo foi ungido com o óleo espiritual da alegria, isto é, com o Espírito Santo, chamado óleo de alegria, precisamente por ser o autor da alegria espiritual"; e ainda: O.CLEMENT, L'Église, Espace de l'Esprit, in Contacts 29 (1977), p. 28: "Saint Grégoire de Nysse reprend à ce propos, et projette dans les profondeurs divines, ces paroles du psaume messianique: Celui qui oint, c'est le Père; Celui qui est oint, c'est le Fils; et l'Esprit constitue l'Onction, l'huile de la Joie. L'huile a toujours été un symbole de joie, et l'Esprit est la joie en personne".

${ }^{32}$ Cf. Oração de Consagação do Óleo do Crisma na Liturgia de Quinta-Feira Santa - Missal Romano, Paulus-Vozes, 1992, p. 242: “...E a tudo isso se acrescenta honra ainda mais alta quando nosso Senhor Jesus Cristo, vosso Filho, exigindo que João o batizasse nas águas do Jordão, e sendo-lhe enviado o Espírito Santo sob a forma de uma pomba, proclamastes pelo testemunho de uma voz que em vosso Filho Unigênito estava todo o vosso amor e claramente confirmastes ser Ele por excelência o Ungido com o óleo da alegria anunciado pelo profeta Davi."
} 
güento) repousa sobre o Filho (o ungido), a fim de que o Filho, por sua vez, possa manifestar, no mesmo Espírito, a sua entrega total e amorosa ao $\mathrm{Pai}^{33}$.

\section{O Espírito Santo no Ministério Público de Jesus}

Todo o ministério público de Jesus transcorre na presença e sob a ação do Espírito Santo. S.Basílio nos diz que o Espírito Santo "sempre esteve presente na vida do Senhor, tornando-se sua unção e seu companheiro inseparável" e que "toda a atividade de Jesus se deu na presença do Espírito" (De Spiritu Sancto, 16: PG 32,140C) . $^{34}$.

Três são, sobretudo, os efeitos da ação potente do Espírito na vida pública de Jesus: Jesus é conduzido pelo Espírito para afrontar a luta contra o espírito do mal (Mc 1,12); Jesus é consagrado com a unção do Espírito para levar a Boa-Nova aos pobres (Lc 4,18) e, no Espírito, Jesus exulta na oração de louvor ao Pai (Lc 10,21). Em outros termos, o Espírito impeliu Jesus a lutar contra o demônio, a pregar o Evangelho e orar ao Pai. Nestas três realidades, podemos ver expressas a tríplice unção de Jesus: régia, profética e sacerdotal $^{35}$.

${ }^{33}$ Cf. J.VIVES Creer en Dios, Padre, Hijo y Espíritu Santo, in AA.VV., El Concilio de Constantinopla I y el Espíritu Santo, Salamanca, Ediciones Secretariado Trinitario, 1983, p. 218: "La revelación de Trinidad no es sólo una revelación sobre el ser de Dios, sino también sobre el ser a quien Dios-Amor se ha entregado la persona del Hijo con la efusión del Espíritu. La revelación trinitaria es el fundamento último de aquella otra revelación inaudita: Lo que haceis a uno de éstos, me lo haceis a mi"'; cf. ainda: P.EVDOKIMOV, L'Esprit Saint pensé par les Pères, in Collectif, Le Mystère de l'Esprit Saint, Maison Mame, 1968, p. 82.

${ }^{34}$ B.GAYBBA, The Spirit of Love, London, Geoffrey Chapman, 1987, p. 21: "In his fascinating book Jesus and the Spirit, Dunn argues very strongly that "Jesus thought of himself as God's Son and as anointed by the eschatological Spirit, because in prayer he experienced God as Father and in ministry he experienced a power to heal which he could only understand as the power of the end-time and an inspiration to proclaim a message which he could only understand as the gospel of the end-time". I find Dunn's arguments convincing. Jesus may well have said little about the Spirit, but that he was conscious of the Spirit's presence within him seems to me to be clear. This means that he must have expected prophecies such as Joel's to be fulfilled soon - and why should he not have led his disciples to expect the same? However, Joel's prophecy could not be fulfilled until after Jesus died. Here we have another important aspect of the link between Jesus and the Spirit: the Spirit is only poured out after Jesus'death and resurrection".

${ }^{35}$ Cf. R.CANTALAMESSA, O Espirito Santo na Vida de Jesus..., p. 20; F.LAMBIASI, Lo Spirito Santo: Mistero e Presenza..., p. 56 e B.CABALERO, Ministerio Profetico de Jesús, in Pentecostes 9 (1971), pp. 54-62. Ainda é oportuna a seguinte declaração: H.PAPROCKI, $A$ Promessa do Pai. A Experiência do Espírito na Igreja Ortodoxa, São Paulo, Paulinas, 1993, p. 23: “... Na perspectiva de Lucas, o combate de Jesus com Satã, começado no deserto, deve continuar na Igreja, a qual, segundo o espírito da doutrina de São Paulo, é o "Corpo de Cristo". São Lucas termina a narrativa da tentação de Jesus no deserto com esta afirmação carac- 
Os Evangelhos sinóticos afirmam que, após o batismo, Jesus foi para o deserto e todos os três atribuem essa iniciativa ao Espírito Santo (cf. Mt 4,1; Mc 1,12; Lc 4,1). Assim, Jesus, "rebento do tronco de Jessé" (Is 11,1), iniciou seu ministério messiânico no deserto, que fora outrora o caminho escolhido por Deus para que Israel atingisse a terra prometida, lugar privilegiado para que o povo de Deus fizesse a experiência do amor de seu Deus. Tentado, à semelhança de Israel, Jesus, como "novo Adão", venceu e derrotou o inimigo. Lucas, bastante sensível à ação do Espírito na vida de Jesus, duplica a menção do Espírito Santo no episódio da tentação ao testemunhar: "Jesus, pleno do Espírito Santo, voltou ao Jordão, era conduzido pelo Espírito Santo ao deserto" $(4,1)^{36}$.

Dessa maneira, no deserto, Jesus, na qualidade de ungido do Senhor, é o "pneumatóforo" messiânico dos últimos tempos, o qual plenifica todas as promessas da efusão do Espírito reservada para os tempos escatológicos (cf. Is 32,15-20; 44,3-5; 59,21). A experiência inaudita do batismo levou Jesus a iniciar a sua atividade pública, a entregar-se totalmente ao anúncio e à instauração do Reino de Deus. Batizado no Espírito Santo e, no mesmo Espírito, tendo alcançado a vitória sobre Satanás, o Christós do Pai agora se encontra em condições de executar a breve e densa linha programática traçada por Pedro em At 10,38: ungido pelo Espírito do Pai, Jesus de Nazaré "passou fazendo o bem e curando a todos aqueles que haviam caído no poder do diabo",37.

Em várias passagens dos evangelhos, encontramo-nos com Jesus se confrontando com as forças demoníacas do poder das trevas (cf. Mc 1,2425.27.34; Mt 8,29; Lc 4,31-37). Ao enfrentá-las e subjugá-las, Ele o faz na potência do Espírito, pelo "dedo de Deus"38, o que, então, revela a natureza

terística: "O diabo o deixou até o tempo marcado" (Lc 4,13); os exegetas vêem nessas palavras o anúncio de combate mais decisivo no horto das Oliveiras e na cruz, combate que, no tempo, não é o último, uma vez que se prolonga nos membros da Igreja de Cristo".

${ }^{36}$ Lucas, no seu particular interesse pelo dado pneumatológico do ser e do operar de Jesus, evidencia a operação do Espírito Santo não só nos primeiros capítulos de seu evangelho $(1,15.35 .41 .67 .80 ; 2,25-27)$, mas ainda no restante dos relatos evangélicos, onde acrescenta diversas passagens não encontradas nos demais evangelhos $(4,1.14 .18 ; 10,21 ; 11,13)$.

37 Cf. F.X.DURRWELL, A Ressurreição de Jesus, São Paulo, Herder, 1969, p. 17: “O traço específico do Ressuscitado, que revela sua messianidade, é o poder soberano sobre todas as riquezas do Espírito (At 2,33). A efusão espiritual é o sinal dos últimos tempos (At 2,16s), e contém todos os bens da promessa. O Espírito é a promessa substantivada". Jesus é o "pneumatóforo" do Pai por excelência - cf. J.DONNELL, Il Mistero della Trinità, Roma, Piemme, 1989, pp. 50-58.

${ }^{38}$ Cf. R.CABIÉ, La Pentecôte - L'Évolution de la Cinquantaine Pascale au Cours des Cinq Premiers Siècles, Paris, Desclée, 1965, p. 234: "Par un rapprochement de textes bibliques, l'évéque d'Hippone identifie le digitus Dei avec l'Esprit-Saint. 'Si c'est par l'Esprit de Dieu que j'expulse les démons, c'est qu'alors le royaume de Dieu est arrivé jusqu'à nous", dit le Seigneur, d'après l'évangile de Saint Matthieu. Mais le passage parallèle en Saint Luc présen- 
carismática de sua missão e, por conseguinte, sua autoridade carismática ${ }^{39}$. Diante do ministério pastoral de Jesus, alguns se admiravam e perguntavam: "Que é isso? Um novo ensinamento com autoridade! Até mesmo aos espíritos impuros dá ordens, e eles lhe obedecem" (Mc 1,27). Ao realizar a obra de libertação que o Pai lhe confiou, Jesus se apresenta como o "Homem carismático que, revestido da força do Espírito, une o homem ao Deus criador e vence por Ele as forças caóticas e destruidoras presentes no coração do homem e no seio da história"40. O Espírito Santo é também para Jesus a força para a evangelização. É muito significativo o fato de que, em Lc 4,18-21, Jesus aplique a si mesmo a profecia de Isaías 61,1-2, acrescentando o hoje daquela Escritura que estava se realizando em sua pessoa. Isso equivale dizer que Ele se autocompreende como o "Ungido", como o Messias, através do qual Deus realizaria definitivamente as promessas feitas a Israel.

Ao aplicar a si a missão profética, Jesus amplia infinitamente o alcance do trito-Isaías, pois com Jesus a figura se torna realidade e cumprimento; Jesus não é mais um dos profetas, mas a realização cabal de todos eles. A Ele o Espírito é dado "sem medida" (Jo 3,34). Ele está em plena posse do Espírito, que n'Ele "permanece" para sempre (cf. Jo 1,32-34). "Entre as características do Cristo carismático, convém, antes de tudo, considerar a ori-

te une variante: “or si c'est par le doigt de Dieu que j'expulse les démons...”. D’où la conclusion: Alors qu'un évangéliste parle du doigt de Dieu, l'autre en donne l'explication, pour montrer que c'est l'Esprit-Saint qui est le doigt de Dieu". Conferir os vários significados de "Dedo de Deus" na Revelação Bíblica em A.PEDRINI, I Simboli Biblici dello Spirito Santo, Milano, Edizioni O. R., 1981, pp. 51-59.

${ }^{39}$ Cf. J.GALOT, L'Aspetto Carismatico della Vita de Gesú, in La Civiltà Cattolica 3038 (1977), pp. 141 e 145: "La natura carismatica della missione di Gesú si manifesta nei miracoli... È vero che quando esercita questa autorità egli lo fa con la potenza dello Spirito Santo e secondo l'intimo orientamento che riceve da lui. Per questo la sua autorità é carismatica"; J.G.D.DUNN, Jesus y el Espiritu, Salamanca, Secretariado Trinitario, 1981, pp. 140-141: "La conclusión que brota de todo esto es la de una autoridad carismática... esta naturaleza carismática de la autoridad de Jesús, la inmediación de su sentido de la autoridad juntamente com la conciencia de referencia personal en gran parte de su enseñaza, es lo que parece que distinguió a Jesús de otros hombres de importancia similar en la historia de las religiones".

${ }^{40}$ Cf.B.GAYBBA, The Spirit of Love London, Geoffrey Chapman, 1987, p. 20: "Jesus'power over evil, thanks to the presence of the Spirit, is seen dramatically in his healings and exorcisms. That exorcisms demonstrate a power over evil is obvious. But for the jews not only exorcisms but healing too was a victory over the forces of evil, since it was believed that sickness was the result of $\sin$ (see, e.g., Jn 9,2), a sign that a person was to some extent under the power of Satan (Lk 13,16). Conferir ainda: A.VERGOTE, O Espírito Santo, Força de Salvação e de Saúde Espiritual, in AA.VV., A Experiência do Espírito Santo, Petrópolis, Vozes, 1979, p. 179: "O homem não se pertence; ou está orientado para Deus ou cai de si mesmo, entregando-se às forças demoníacas. Diante desses doentes, Jesus se apresenta como o Homem carismático que, revestido da força do Espírito, une o homem ao Deus criador e vence por ele as forças caóticas e destruidoras." 
entação fundamental no sentido do amor que exclui um profetismo negativo de condenação ou de vingança divina. Em seguida, é importante notar a finalidade espiritual que guia todas as manifestações sensíveis da potência carismática" ${ }^{41}$.

Na medida em que evangeliza os pobres, Jesus instaura o Reino de Deus operando milagres, curando os enfermos, expulsando os demônios e inaugurando a era messiânica com a Boa-Nova da libertação (Mt 8,29-34; 9,1-7.18-26; Mc 1,14-15.21-28.32-34; Lc 4,40-41;5,12-16). Em todos esses sinais se pode ver uma manifestação clara daquela potência pneumatológica e uma prova evidente de que o Reino está se estabelecendo, de fato, na história (cf. Mt 12,28). Os portentos que tornam presente o reino de Deus nos fazem recordar as Magnalia Dei operadas por Iahweh em favor de seu povo. São justamente tais portentos ou ações maravilhosas (dýnamis), que qualificam Jesus como um taumaturgo carismático.

Como um profeta carismático, Jesus desempenha seu ministério público pleno de criatividade pneumática. Como fruto de sua unção messiânica e enriquecido com a dýnamis salvífica de Deus, Jesus realiza a missão libertadora para a qual foi enviado. Nesse sentido, o próprio Pneûma torna-se o locus e o âmbito do "ser-criativo" de Deus. Assim é que Jesus emerge como o "Filho amado" que, no impulso do Espírito, lança-se totalmente à obediência da vontade do Pai e à entrega pela causa do reino. Tendo como único alimento "fazer a vontade do Pai" (cf. Jo 4,34), Jesus, na sua plena diafania, aparece como alguém totalmente aberto ao Espírito de Deus e, sem cessar, voltado para os homens, seus irmãos.

$\mathrm{Na}$ força do Espírito do Senhor, Jesus torna-se um pneumático escatológico, na medida em que antecipa em meio aos homens o Reino definitivo. Confrontando-se a todo instante com o drama do pecado instalado na história e no coração dos homens, Jesus propõe a "utopia" do Reino e garante que a potência do Espírito, do qual é portador, é a única força capaz de vivificar as caóticas manifestações do anti-reino na história. O Reino de Deus é "salvação em ato", graças ao impacto que o Espírito Santo exerce na história. Quem nega esta verdade, como faziam os fariseus, incorre na "blasfêmia contra o Espírito" (cf. Mt 12,31-32; Mc 3,28-29; Lc 12,10), pecado imperdoável de cegueira, com o qual se refuta a luz da evidência messiânica (cf. Jo 11, 4-5.11-12; Jo 9, 5.39.41).

Em terceiro lugar, o Pneûma é a alma da comunhão que se estabelece entre Jesus e seu Pai. Em diversas cenas do evangelho vemos Jesus, que tem necessidade de estar diante do Pai em oração e se deleita com essa atitu-

\footnotetext{
41 J.GALOT, L'Aspetto Carismatico della Vita de Gesú, in La Civiltà Cattolica 3038 (1977), p. 148.
} 
de (cf. Lc 3,21-22; 5,15-16; 6,12-13; 111-4). A oração foi, por assim dizer, o sitz im leben no qual Jesus vivia mergulhado no Pai.

Adentrando um pouco o mistério da oração de Jesus, deparamo-nos com a profunda e singular intimidade com que se relacionava com Deus Pai: $A b b a$ ! Esta expressão, que dá todo o sentido à oração de Jesus, é portadora de uma impressionante novidade em sua espiritualidade. Nesse sentido, parafraseando Paulo, poderíamos dizer que é sob um influxo pneumático que Jesus se dirige a Deus como Abba!, Pai! (cf. Rm 8,15-16; Gl 4,6).

O mesmo Espírito que propicia a Jesus descobrir o Pai como Abba, leva-o também a "exultar de alegria" e louvar o "Senhor do céu e da terra" (Lc 10,21). Assim, vemos que o Espírito, como óleo de exultação e alegria (S1 44,8; Hb 1,9), suscita em Jesus uma oração de louvor e exultação. Lucas, ao afirmar que Jesus "exultou de alegria sob a ação do Espírito Santo", quer mostrar-nos que Jesus fruía da alegria em sua experiência espiritual e que desempenhou sua missão evangelizadora na alegria. "Jesus exulta pela paternidade divina: exulta porque lhe foi dado revelar; exulta, por fim, por uma como que irradiação especial da mesma paternidade divina sobre os pequeninos. E o evangelho qualifica tudo isto como uma exultação no Espírito Santo" $"$.

Portanto, a ação do Espírito Santo resplandece em toda a vida de Jesus e no arco de todo o seu ministério público. Graças ao Espírito é que Jesus possui a "vida em si mesmo" (Jo 5,21) e a sua passagem no mundo deixa um sulco fecundo, para que "todos aqueles que $\mathrm{O}$ receberem" tenham o poder de "se tornarem filhos de Deus" (Jo 1,12).

Como o pneumatóforo messiânico por excelência, Jesus possui a consciência de que a glória de Deus refulge em sua face (cf. 2 Cor 4,6). Nesse sentido, podemos dizer que todo o seu ser e o seu operar, seu mistério e ministério, estavam sob uma "orientação epiclética", pois, de fato, a unção que o Espírito exerce, intratrinitariamente, explicita-se na realidade extratrinitária, como que uma "grande epíclese" pairante e atuante em toda a história da salvação. Fica claro que isso só nos foi dado a conhecer pela missão messiânica que o Pai conferiu a Jesus.

Esse poder pneumático se desencadeia em todos a práxis pastoral de Jesus, sobretudo quando se deve confrontar com as potências cativas que

42 JOÃO PAULO II, DeV n. 20. Conferir: J.O’DONNEL, Il Mistero della Trinità, Roma, Editrice Pontificia Università Gregoriana, Piemme, 1989, p. 55: "Gesù non solo percepì in modo del tutto particolare la relazione al suo Dio como $A b b a$, ma anche ebbe coscienza di se stesso come portatore straordinario dello Spirito". É muito oportuno para um estudo mais aprofundado da experiência que Jesus faz do Pai como Abba o estudo de G.Schneider: G.SCHNEIDER, El Padre de Jesús - Visión Biblica, in AA.VV., Dios es Padre, Salamanca, Secretariado Trinitario, 1991, pp. 59-100. 
pretendem manter os homens sob o seu jugo. Levando ao clímax a sua luta em prol da libertação dos filhos de Deus, Jesus, conduzido pelo Espírito do Pai, aceita livre e obedientemente o seu "batismo de sangue" e abraça a cruz. Mas, na manhã da páscoa, recupera a vida mediante a ressurreição e agora, com seu corpo glorioso, torna-se "Espírito vivificante" para a vida do mundo $(1 \mathrm{Cor} 15,45)^{43}$.

\section{O Espírito Santo no Mistério Pascal de Jesus}

Cabe-nos agora considerar o papel do Espírito Santo no Mistério Pascal de Jesus, sobretudo no seu núcleo fundamental, isto é, na sua morteressurreição-glorificação.

Desde o início de sua vida terrena e, em particular, após o seu batismo, Jesus viveu intensamente, na força do Espírito, a sua condição de Filho de Deus. O Espírito que o conduziu à auto-experiência de "Filho predileto" do Pai (Lc 4,21-22) e a atuar como tal durante o seu ministério messiânico, é o mesmo que o convida a abandonar-se inteiramente aos misteriosos desígnios do Eterno. "Será que Jesus adivinhou, então, que o seu batismo no Espírito significaria para Ele o batismo no sangue (cf. Mc 10,38) e que a última autotranscendência para Deus se consumaria na cruz?"44.

Segundo João, todo o ministério de Jesus era como que direcionado e polarizado para a "hora" decisiva e definitiva no plano de Deus (cf. 2,4; 7,30; $8,20 ; 12,27 ; 17,1)$; nesse contexto, o significado teológico da "hora" de Jesus é, basicamente, bipolar: refere-se à sua paixão-morte e à sua ressurreição-

\footnotetext{
${ }^{43}$ Cf. L.E.SAntos nOGUEIRA, O Espirito e o Verbo: As Duas Mãos do Pai, São Paulo, Paulinas, 1995, p. 72: "O Cristo está penetrado do Espírito e vice-versa. Na unidade do Pai, as Pessoas divinas vivem, pericoreticamente, a essencialidade do Amor, em mútua doação e acolhimento. Na existência histórica de Jesus, o Verbo e o Espírito se encontram indelevelmente unidos. Juntos, configuram a união hipostática de Deus com uma humanidade. Da graça incriada, emerge a santificação do Cristo, processada em sucessivos pentecostes. Mergulhado no Espírito, Jesus abre-se crescentemente ao Pai em obediência filial, como servidor do Amor. Quando morto na cruz, é assumido gloriosamente pelo Pai e constituído Senhor na dinâmica recriadora do Espírito Santo. Herdando a plenitude da Vida, o Filho humanizado de Deus se assenhora do destino salvífico de toda a criação, podendo doravante intervir em todas as realidades e situações históricas pela mediação graciosa do Espírito".

${ }^{44}$ H.MÜHLEN, Fé Cristã Renovada ..., p. 151; cf. R.LAVATORI, Il Dono di Dio..., p. 125: "A morte de Jesus, de fato, é o cume da sua realidade filial. Ele é o Verbo voltado para Deus (Jo 1,1), é o Unigênito imerso no seio do Pai (Jo 1,18)... Ele é plenamente o Filho voltado para o Pai, porque se oferece à morte para aderir à vontade paterna $(\mathrm{Hb} 9,14)$, a fim de testemunhar o seu amor supremo, que está pronto a antepor a Verdade de Deus a qualquer lógica humana, a custo do sacrifício da própria vida".
} 
glorificação ${ }^{45}$. Sobretudo a "hora" pascal é, para João, a "hora" do Espírito. Para dizer que Jesus "morre", João não usa o termo "expirar" de Mc 15,37 e nem a expressão de Mt 27,50, "entregar o espírito", mas cunha uma fórmula nova: "transmitir o espírito" ("paradídomi tò Pnêuma" - cf. Jo 19,30); uma fórmula de duplo sentido na qual, além do significado mais óbvio de "morrer", transparece aquele de "transmitir", "comunicar" o sopro de Deus (o verbo usado por João, "paradídomi", traz em si uma forte conotação de transmissão, de comunicação de algo, de passar adiante - cf. Mt 25,20; Mc 15,15; Lc 22,22; At 6,14; 2 Pd 2,21) ${ }^{46}$.

Elevado na cruz, Jesus atinge, portanto, a sua "hora", onde se entrega livremente ao único que o pode salvar (cf. Jo 10,18). Naquele momento, ele é, em todo o seu ser, como que uma "epíclese viva", que brada aos céus em oração ${ }^{47}$. No seu sacrifício oblativo, Jesus era todo oração e culto de louvor

${ }^{45}$ Cf. F.DE LA CALLE, A Teologia do Quarto Evangelho, São Paulo, Paulinas, 1978, pp. 133-137; cf. P.LARERE, Baptism in Water and Baptism in the Spirit, Minnesota, The Liturgical Press, 1993, p. 16: "This baptism of Jesus (of Jordan) where the Holy Spirit manifests himself is a veritable anticipation of his baptism in blood on the cross. For Jesus there provides the true significance of the gesture of his humiliation on calvary and of his recovery by the Father on the day of his resurrection. "He was pushed down, becoming obedient even unto death, death on a cross. That is why God raised him up to majesty..." (Phil 2,8-9)."

${ }^{46}$ Cf. H.U.VON BALTHASAR, Glória (Vol VII), Madrid, Encuentro Ediciones, 1989, p. 326: 'En su 'abandono' total (más allá de la 'autoridad' y de la 'pobreza') el Hijo exhala su Espíritu, el Espíritu del amor que llegó 'hasta el final', y en este mismo instante el Padre puede disponer de modo nuevo y distinto del Pneûma, mientras el Hijo exhala el Espíritu del amor en la más extensa debilidad, el Padre puede mostrar la suprema fuerza (dýnamis) y la gloria (dóxa) de su Espíritu de amor resucitado por medio del Pneûma al Hijo (1Pd 3,18; Rm 8,11 ; 1 Tm 3,16) como 'cuerpo espiritual' (1Cor 15,43s.), por tanto, como un cuerpo ya no ligado a las delimitaciones terrenas entre cuerpo y cuerpo, yo y tú, y que por eso, en virtude del Pneûma del el és (ha llegado a ser) Señor, que él 'irradia' y en cuya esfera sin límites él domina, puede abarcar también nuestros espíritus y nuestros cuerpos".

${ }^{47}$ P.REGAN, Encontro com Cristo na Oração Comunitária, in " $E$ Vós, quem dizeis que Eu sou?", Rio de Janeiro, Lumen Christi, 1985, p. 77; cf. J.LÓPEZ MARTÍN, La Eucaristía, Pentecostés Permanente del Espíritu "que da la Vida", in AA.VV., El Concilio de Constantinopla I y el Espíritu Santo..., p. 17: "La glorificación de Jesús, su resurrección de entre los muertos y su ascensión a los cielos a la derecha del Padre (cf. Mc 16,19; Hch 1,9ss.) es la gran epíclesis divina en la que nuestro sumo Pontífice y Mediador pide al que da todo bien que envíe el Espíritu Santo, y el Padre, en respuesta al Hijo fiel y obediente (cf. Fil 2,8) que en el Espíritu Eterno se ofreció en sacrificio (Hb 9,14), da paso a la economía de Pentecostés"; e ainda: Id.Ibid., No Espírito e na Verdade, Vol. I, Petrópolis, Vozes, 1996, p. 35: "Quando Jesus morre, a invocação que brota de seus lábios é a resposta ao chamado do Pai, que o consagrou como Servo santificado e ungido para o sacrifício: "Tu és o Filho amado, de Ti eu bem me agrado" (Mc 1,11e par.; cf. Mc 9,7 e par.; At 10,38; Hb 1,5-6; 5,5-10). Era a epiclesis (cf. $\mathrm{Hb} 9,14)$ que santificava a oferta de si mesmo e convertia a morte de Jesus em sacrifício de expiação e eucaristia perfeita (cf. Jo 17,19; Hb 9,14; 10,4-10). Desse modo Jesus concluía 
ao Pai. Na cruz, efetivamente, Jesus consuma o seu múnus sacerdotal como o sumo sacerdote da nova aliança, como o mediador perfeito que inaugura o novo sacerdócio e o novo santuário, temática tão cara à teologia da carta aos Hebreus (cf. Hb 4,14-5,10; 7,20-28; 8,1-13; 10,11-18). A efusão do Espírito Santo está estreitamente conexa à "hora" de Jesus e dela é dependente (cf. Jo $2,4 ; 8,20 ; 17,1)$. Nesse sentido, João Paulo II diz que "o Espírito vem à custa da partida de Cristo, vem à custa da cruz operadora da redenção pelo poder de todo o mistério pascal de Jesus Cristo" 48 .

A obra da redenção é paterna e filial e, por isso, plena do Espírito Santo. É no Espírito que Deus é Pai e que, desde a sua origem, Jesus é o Filho (cf. Lc 1,35); é nele, enfim, que Jesus se oferece ao Pai (cf. Hb 9,1) e que ressuscita (cf. Rm 8,11) ${ }^{49}$. Enfocando todo o tempo o teor pneumatológico do Mistério Pascal de Jesus, não podemos perder de vista a dimensão trinitária desse mesmo mistério, em particular no que concerne à sua ressurreição. É à luz da pedagogia bíblica isso se verifica de modo bastante esplícito. Destarte, para Paulo, Jesus, ressuscitado pelo Pai, por meio do Espírito, foi "estabelecido Filho de Deus com poder" mediante o "Espírito de santidade" (cf. $\mathrm{Rm} 1,4)$. A afirmação de que Cristo foi ressuscitado dos mortos pela "glória do Pai" (cf. Rm 6,4), certamente significa a mesma coisa na teologia do apóstolo. Noutro lugar lê-se que Jesus foi "justificado no Espírito" (cf. 1Tm 3,16 ), o que significa que o Kýrios foi exaltado pelo Pneûma do Pai por ocsisião de sua ressurreição, a qual, por seu turno, atesta sua justiça e divindade. Em sua primeira carta, Pedro, complementando a intuição paulina, afirma que Jesus, "morto segundo a carne", foi "vivificado no Espírito" (cf. 1Pd 3,18). "Ressuscitado dos mortos e constituído Senhor e Cristo, Jesus é então revelado o unigênito, como Filho; Deus é revelado como a única fonte da vida como Pai; o Espírito é revelado como dom de vida do Pai e do Filho"50.

O "Santo Pneûma" se apresenta como um agente da ressurreição de Jesus $^{51}$ uma vez que o Pai o ressuscita no Espírito (cf. Rm 8,11). A obra da

toda uma vida de fidelidade e de santidade. Por isso ele é o nosso "amém", para a glória e louvor do Pai, no Espírito Santo (cf. 2Cor 1,20; Ap 3,14)".

48 DeV n. 14.

${ }^{49}$ F.X.DURRWELL, L'Esprit Saint de Dieu..., p. 52; cf. P.FERLAY, Dieu, le Saint Esprit..., p. 75: "C'est le Saint-Esprit qui permet à Jésus le Fils de parler et de mourir aussi... C'est cet Esprit d'amour qui Jésus mourant remet au Père, sachant qu'il a vraiment "tout accompli". En donant au Père son dernier souffle, Jésus lui remet l'Esprit de leur amour éternel".

${ }^{50}$ P.REGAN, Encontro com Cristo na Oração Comunitária..., p. 78; cf. B.SESBOÜÉ, Pedagogia do Cristo - Elementos de Cristologia Fundamental, São Paulo, Paulinas, 1997, p. 52.

${ }^{5}$ Cf. F.X.DURRWELL, A Ressurreição de Jesus..., p. 107: "O Santo Pneuma se apresenta como um agente da ressurreição... o Pai está na origem da ação ressuscitante, mas esta é levada a efeito por meio do Espírito. Cada uma das causas reclama sua parte; o Espírito se 
ressurreição mostra-nos ainda que o Espírito é o poder gerador de Deus, pois, "ressuscitando Jesus no Espírito Santo, Deus o gerou divinamente". "Jesus é ressuscitado na plenitude da vida filial ao mesmo tempo pela glória, pelo poder e pelo Espírito: três nomes para indicar a causa única da ressurreição, que é o Espírito Santo... ora, o Espírito é o poder e a glória de Deus em sua paternidade" 52 . É importante ainda ressaltar a dinâmica trinitária no fato da ressurreição. A estrutura trinitária dos relatos da ressurreição, tão bem sublinhada pelo Kerygma apostólico, nos conduz a uma compreensão integrada do mistério da ressurreição: a paternidade eterna de Deus, a obediente e solidária entrega do Filho e a diakonia operante do Espírito-Amor. Mais que uma metafísica especulativa que intentaria conciliar o número e a unidade, trata-se aqui de uma mística cristã como experiência ontológica do Mistério Trinitário-Pascal.

Aquele que, no centro da Trindade, é o vínculo da unidade de amor na diversidade das Pessoas divinas é a dýnamis unificante que triunfa em Jesus sobre todas as forças de dispersão da morte. A manhã da páscoa inaugura aquele "dia" profeticamente anunciado pelo salmo 117,24, que a tradição cristã, desde a primeira hora, aplica à ressurreição de Cristo. Também o Salmo 2,9 ("Tu és meu o filho, eu hoje te gerei") é aplicado na mesma perspectiva (cf. At 13,33).

A ressurreição de Jesus marca o início da nova criação, onde o Espírito de Deus, de modo análogo àquela de Gn 1,2, paira sobre o caos da morte, a fim de restituir a vida. "A ruah de Iahweh, que já na criação 'protegia' o mundo e o 'incubava' para que surgisse a vida, esse poder 'maternal' pessoal e vivificante, preside a essa nova criação, que é a ressurreição de Cristo" ${ }^{53}$.

A ressurreição confere ao Filho de Deus, sobretudo, uma "existência pneumática" através da qual se torna "Espírito vivificante" ("Pneûma zoopoioûn" - cf. 1Cor 15,45) ${ }^{54}$. Através dela, Jesus é plenificado com o Espí-

revela aqui e em outras partes, como a Pessoa agente, o princípio executivo que exerce uma atividade quase instrumental que lhe é própria.

${ }^{52}$ F.X.DURRWELL, O Pai: Deus em seu Mistério, São Paulo, Paulinas, 1990, p. 11; cf. Id. Ibid., p. 25: “A glória é reveladora por natureza, uma vez que ela é o próprio mistério em sua irradiação... a glória de Deus, como todo o mistério divino, é de natureza trinitária. Ela emana do Pai e brilha em Cristo, mas se identifica com o Espírito Santo... Jesus é ressuscitado na plenitude da vida filial ao mesmo tempo pela glória, pelo poder e pelo Espírito: três nomes para se designar a única causa da ressurreição, que é o Espírito Santo... ora, o Espírito Santo é o poder e a glória de Deus em sua paternidade. Fazendo aparecer Jesus na sua dóxa, o Espírito se mostra como o "Espírito da Verdade", isto é, como o Espírito por meio do qual se experimenta a Verdade, que outra coisa não é senão o próprio Jesus".

${ }^{53}$ P.FERLAY, Jesus, nossa Páscoa, São Paulo, Paulinas, 1978, p. 107

${ }^{54}$ Cf. H.MÜHLLEN, Una Mystica Persona..., p. 190: "L'esistenza pneumatica del Figlio di Dio nella gloria viene espressa soprattuto da lCor 15,45: Il nuovo Adamo (Cristo) è diventato 
rito do Pai, a ponto de se tornar, na qualidade de "novo Adão", "espírito vivificante" (1Cor 15,45) e fonte da vida para o mundo. De fato, o "pentecostes pascal" ocorrido na manhã da páscoa é a plena efusão do Espírito sobre Jesus ${ }^{55}$, que lhe confere glória e poder. O poder ressuscitante de Deus glorifica Jesus, exaltando-o sobremaneira e constituindo-o "Senhor" e "Cristo" (cf. Fl 2,6-11) ${ }^{56}$.

Entretanto, tendo sido cumulado com o dom do Espírito em plenitude, o ressuscitado torna-se também doador do Espírito (cf. Jo 7,37-39). Uma vez glorificado, tem em si a potência da vida nova, com a qual pode dar a vida a todos os homens (cf. Jo 10,10); o Corpo de Cristo, cheio do Pneûma na ressurreição, torna-se fonte de vida para o mundo ${ }^{57}$. Não se pode considerar a ressurreição de Cristo como um ato transitório. Ressuscitando Jesus dentre os mortos, Deus o coloca numa nova condição, num estado de "poder" glorioso e salvífico. "A intervenção pneumática de Deus na ressurreição estabeleceu exatamente Jesus como Messias dotado de dýnamis soteriológica. Instrumento divino da ressurreição, o Espírito Santo investiu Jesus, uma vez para sempre, com seu poder" ${ }^{\prime 5}$.

Isso pode ser biblicamente verificado em Rm 8,1-13, por exemplo, em que Paulo realça a vertente pneumatológica da ressurreição de Jesus (cf. “... o Espírito que ressuscitou Jesus..." - cf. 8,11), o que, naturalmente gera novas conseqüências não só para o atual estado do ressuscitado (Kýrios), mas ainda para todos aqueles que, em virtude do Pneûma vivificante, passam a

Spirito vivificante (pneûma zoopoioûn). Nel contesto non si parla della chiesa, ma della risurrezione dei morti; dal passo, tuttavia, noi possiamo comprendere come il Pneûma agisca in Cristo, e como sia possibile che l'unione con lui operi la vita."; cf. ainda: F.X.DURRWELL, $A$ Ressurreição de Jesus..., pp. 240-242: “A missão do Pneûma pessoal, cuja presença em nós é a raiz da vida, é questão do Pai; é Ele que envia o Pneûma de filiação, assim como é Ele que ressuscita Cristo e seus fiéis."

${ }^{55}$ Cf. F.X.DURRWELL, L'Esprit Saint de Dieu..., p. 23: "Toute la promesse eschatologique s'accomplit dans la résurrection de Jésus: la pleine effusion de l'Esprit, le triomphe de la puissance, la fulgurance de la gloire. Le Christ est ressuscité par l'Esprit (Rm 8,11), "il vit par la puissance" (2Cor 13,4), il est "ressuscite par la gloire" (1Cor 15,45)".

${ }^{56}$ Cf. C.VAGAGGINI, El Sentido Teologico de la Liturgia, Madri, B.A.C., 1965, p. 248.

${ }^{57}$ Cf. JOÃO PAULO II, O Espírito Santo na Ressurreição de Jesus, in L'Osservatore Romano 32 (1990), p. 8; cf. ainda: F.X.DURRWELL, Lo Spirito del Padre e del Figlio, Roma, Città Nuova, 1990, pp. 35-47.

${ }^{58}$ Cf. H.C.JOSÉ MATOS, O Espírito Santo no Mistério de Cristo e dos Cristãos, Versão Portuguesa do Estudo de Giovani Helewa, Lo Spirito Santo nel Mistero di Cristo e del Cristiano, Roma, Pontifício Instituto de Espiritualidade "Teresianum", 1978, p. 14; Id. Ibid: "Ressuscitando-o dos mortos, Deus colocou o Cristo Jesus numa nova condição, num estado de "poder" glorioso e salvifico... a intervenção pneumática de Deus na ressurreição estabeleceu exatamente Jesus como Messias dotado de "dýnamis" soteriológica. Instrumento divino da ressurreição, o Espírito Santo investiu Jesus, uma vez para sempre, com o seu poder”. 
tomar parte dessa mesma condição de glória, quer em nível pessoal, eclesial, comunitário-social ou até cósmico. A Ressurreição de Jesus significa a plena espiritualização e deificação da sua humanidade assumida. A humanidade de Jesus é perfeitamente divinizada e glorificada. A partir da ressurreição, Jesus passa a existir na forma gloriae. Disso concluímos que, após a ressurreição, a humanidade glorificada de Jesus passa a ser o veículo da comunicação do Espírito para todo o universo. O dom do Espírito Santo sobre toda a carne testemunha que a glória do Espírito de Jesus, uma vez tendo subido ao céu, plenifica todas as coisas. Segundo L.F.Ladaria, esse enfoque nos introduz numa cristologia pneumática, que é uma cristologia dinâmica; ela nos ajuda a enfocar unitariamente o mistério da importância da autocomunicação de Deus ao homem por meio Jesus e no Espírito ${ }^{59}$.

Ressaltamos aqui uma dessas conseqüências que diz respeito ao que se refere à Igreja. H. Mühlen sustenta que a Igreja é a "continuação histórica da unção de Jesus com o Espírito Santo". Após ter considerado o aspecto histórico-salvífico da unção de Jesus, em particular no mistério de sua ressurreição, Mühlen passa a mostrar como o Espírito Santo realiza o perpetuar histórico da obra redentora de Jesus no "grande-eu" de Cristo em sua Igreja. Sem dúvida alguma, é essa uma perspectiva que ilumina e aprofunda o relacionamento harmônico e estreito que, cada vez mais, a teologia está procurando entre a cristologia, eclesiologia e a pneumatologia ${ }^{60}$. É essa também a perspectiva de L.Boff ao dizer que a Igreja não possui apenas uma origem cristológica, mas também, de modo particular, uma origem pneumatológica; diz ainda que essa origem pneumatológica da Igreja merece um aprofundamento maior no pensar teológico ${ }^{61}$.

${ }^{59}$ Cf. L.F.LADARIA, El Espíritu Santo en Hilario de Poitiers, in AA.VV., Credo in Spiritum Sanctum, Atti del Congresso Teologico Internazionale di Pneumatologia, Vol. I, Vaticano, Libreria Editrice Vaticana, 1983, p. 253.

${ }^{60}$ Cf. H.MÜHLEN, Una Mystica Persona..., pp. 269-318; M.SERENTHÀ, Jesus Cristo, Ontem, Hoje e Sempre, São Paulo, Salesiana Dom Bosco, 1986, p. 41: "Resta a tarefa de ampliar a reflexão na linha da elaboração de uma Pneumatologia propriamente dita: O discurso cristológico não pode deixar de desembocar no discurso pneumatológico.

${ }^{61}$ Cf. L.BOFF, A Igreja, Sacramento do Espírito, in O Espírito Santo: Pessoa, Presença e Atuação, H.C.LIMA VAZ, Petrópolis, Vozes, 1973, pp. 110-111: “A Igreja não possui somente uma origem cristológica, mas também, de modo particular, uma origem pneumatológica. Enquanto ela se origina do Espírito Santo, que é o Espírito de Cristo, ela possui uma dimensão dinâmica e funcional; ela se define em termos de energia, carisma e construção do mundo, porque o "Espírito sopra onde quer" (Jo 3,7) e "onde está o Espírito do Senhor, aí reina a liberdade" (2Cor 3,17). A origem cristológica e pneumática da Igreja merece um aprofundamento maior."; cf. ainda: JOÃO PAULO II, L'Osservatore Romano 32 (1990), p. 8: "Pode-se dizer que a missão de Cristo atinge verdadeiramente o seu auge no Mistério Pascal, onde a estreita relação entre a cristologia e a Pneumatologia se abre, diante do olhar do crente e da investigação do teólogo, sobre o horizonte escatológico.” 


\section{Conclusão}

Segundo I.Oñatibia, a preocupação pneumatológica que, sobretudo nos últimos anos, tem desafiado a Igreja e o teólogo, mostra que surpreendentes riquezas nesse campo estão reservadas para a pesquisa teológica. Entretanto, lembra-nos o autor que não se trata tanto de desenvolver a pneumatologia como um tratado especial, quanto de aprofundar a dimensão pneumatológica do mistério cristão em cada uma de suas fases e níveis, sobretudo no que se refere à cristologia, à eclesiologia, à sacramentária, à catequese e à pastoral ${ }^{62}$. Tudo o que até expusemos intenta exatamente corroborar e aprofundar tal preocupação.

O itinerário que perfizemos tinha em vista realçar que a revelação plena do Deus Uno e Trino somente se torna possível por meio do Filho de Deus e do Espírito Santo. O Verbo encarnado, ao mesmo tempo que nos revela o Pai, torna-se, pelo seu Mistério Pascal, o veículo pelo qual o Espírito Santo é derramado nos corações. "A novidade que caracteriza a concepção neotestamentária do Espírito Santo é a original e única relação entre Cristo e o Espírito. O Espírito é o Espírito de Cristo, e é pressuposto e meio para conhecer Deus Trindade" $"$.

Assim como na Trindade o Espírito Santo é o elo de amor eterno entre o Pai e o Filho, na Encarnação torna-se o vínculo de união entre o Verbo e a humanidade. Mateus e Lucas, principalmente, registram que as diversas circunstâncias que envolveram o Mistério da Encarnação possuem um caráter pneumático (cf. Mt 1,20; Lc 1,15.42; 2,26). Entretanto foi o evento do batismo de Jesus no Jordão que tomamos como paradigma para o entendimento da cristologia pneumatológica que tentamos esboçar; a razão disso é que a unção de Jesus no Jordão ou o seu "batismo no Espírito" é de grande importância para o seu mistério e ministério, bem como para a vida da Igreja e dos cristãos. Daí entendermos o valor que a Igreja primitiva dava à manifestação do Espírito Santo no batismo de Jesus, que outra coisa não era senão a "un-

\footnotetext{
${ }^{62}$ Cf. I.OÑATIBIA, Por una Recuperación da la Dimensión Pneumatológica de los Sacramentos, in Phase 96 (1976), p. 439: "Es mucho el camino recorrido, pero queda todavía un largo camino por andar. La recuperación, por los occidentales, de la dimensión peneumatológica de la Iglesia y de los Sacramentos, más que un logro consumado, es una tarea aún por realizar... trabajos como el de Emmanuel-Pataq Siman constituyen una revelación de las sorprendentes riquezas que están aguardando el labor paciente del investigador. Las relaciones CristoEspíritu, Iglesia-Espíritu, Sacramentos-Espíritu quedan ahí como un reto y un acicate para el teólogo. Non se trataría tanto de desarrollar la pneumatología como tratado especial, cuanto de ahondar en a dimensión pneumatológica del mistero cristiano en cada una de sus fases y niveles."

${ }^{63}$ AA.VV., Comissão Teológico-Histórica do Grande Jubileu do Ano 2000..., pp. 47-48.
} 
ção" que dá significado a toda a sua obra salvífica (cf. At 10,38). Na expressão de J. Moltmann, só se pode compreender a "história crística de Jesus" a partir da efusão pneumática do Jordão. É na qualidade de "Ungido" do Senhor que Jesus exerce toda a sua atividade pública, o seu ministério messiânico. Aplicando a si a profecia messiânica de Is 61,1-2, Jesus, na Sinagoga de Nazaré, mostra que a sua missão teria um cunho essencialmente epiclético-pneumatológico (cf. Lc 4,18-19). Aqui não nos deteremos nas inúmeras passagens dos evangelhos que fortemente evidenciam essa realidade.

A ressurreição de Jesus está no centro da fé cristã. Ela é, de forma privilegiada, uma revelação da unitrinitariedade de Deus. A dýnamis operante do Espírito é o poder pessoal e vivificante enviado do Pai, é a Pessoa que preside à nova criação, que é a Ressurreição de Jesus. Na verdade Jesus não se ressuscitou dos mortos; foi ressuscitado por um Outro, o Deus ao qual se entregou (cf. At 2,36; 3,15; 13,37). É a Ressurreição que outorga ao Filho de Deus uma "existência pneumática", pela qual Ele mesmo se torna "Espírito vivificante" (Pneûma zoopoioûn), "novo Adão" e fonte de vida para o mundo (cf. 1Cor 15,45).

No parecer de H.Mühlen, anteriormente citado, a redescoberta da cristologia pneumática, empreendida nos últimos anos, gera importantíssimas conseqüências para a eclesiologia. A Igreja, sob esse prisma, pode ser tida, de acordo com Mühlen, como a "continuação histórica da unção de Jesus com o Espírito Santo". Assim, a cristologia bíblica, fundamentalmente pneumática, deve desembocar numa eclesiologia também pneumática. Não é sem razão que o perfil pneumatológico da eclesiologia tem sido, nesses últimos três decênios do pós-Concílio, um alvo de interesse da reflexão teológica contemporânea. Julgamos que isso seja de capital importância para o aprofundamento do binômio "cristologia-eclesiologia", mormente na esfera dogmático-litúrgica.

\section{Resumo}

Percorrendo algumas etapas da vida de Jesus de Nazaré, procuramos mostrar a capital importância da presença e da ação do Espírito Santo ao longo do seu ministério messiânico, com o intuito de matizar, sob o prisma escriturístico, a centralidade do que poderíamos denominar "Cristologia pneumática". Com efeito, é à luz da esteira messiânica que os apóstolos interpretaram os textos messiânicos que falavam do "Espírito do Senhor", e viram em Jesus o descendente de Davi dotado da plenitude desse mesmo Espírito. Assim, a efusão pneumática, objeto da promessa, é agora destinada a todos os povos. É tarefa imprescindível da reflexão teológica aprofundar a 
dimensão pneumatológica do mistério cristão em cada uma de suas fases e níveis, sobretudo no que concerne refere à cristologia, à eclesiologia, à teologia sacramentária, à catequese e à pastoral.

Palavras-Chave: Cristologia, Pneumatologia, Mistério Pascal, Eclesiologia, Catequese, Pastoral.

\begin{abstract}
Walking along some stages of Jesus from Nazareth's life, we intend to show the capital importance of the Holy Spirit's presence and action all way through his messianic ministry in order to make evident, through a Holy Scripture's approach, the centrality of what we may name "pneumatic Christology". As a matter of fact, it is a common place to say that, enlightened by this so called messianic approach, the Apostles interpreted the messianic texts that mentioned the "Spirit of the Lord" and also saw in Jesus, the descendant of David fully gifted with the same Spirit. Thus the pneumatic effusion, as object of the promise, is destined now to all nations. It is an indispensable task of the theological reflection to deepen this pneumatic dimension of the Christian mystery in each of its phases and levels, especially concerning Christology, Ecclesiology, Theology of the Sacraments, Catechesis and pastoral work.
\end{abstract}

Keywords: Christology, Pneumatology, Paschal Mistery, Ecclesiology, Catechesis, Pastoral Work.

\title{
Luiz Fernando Ribeiro Santana
}

Doutor em Teologia pela PUC-Rio Professor do Departamento de Teologia da PUC-Rio

E-mail: 1.fernando@superig.com.br

Artigo Recebido em 13/07/2010

Artigo Aprovado em 17/09/2010 